\title{
EEL BUSINESS DEVELOPMENT STRATEGY IN PT LAJU BANYU SEMESTA (LABAS)
}

\section{Hesti Indri Purwaty*1, Rina Oktaviani**), and Ono Suparno***)}

*) School of Business, Bogor Agricultural University

SB IPB Building, Pajajaran Road, Bogor, Indonesia 16151

**) Department of Economic, Faculty of Economics and Management, Bogor Agricultural University

Jl. Agatis, IPB Dramaga Campus Bogor 16680

${ }^{* * *)}$ Department of Agroindustrial Technology, Faculty of Agricultural Technology, Bogor Agricultural University Building Fateta Floor 2, IPB Darmaga Campus, Bogor 16680

\begin{abstract}
The objectives of this research were to illustrate the business model of PT Labas with the Business Model Canvas (BMC) approach, to develop the business development strategy of the company, and to describe the development of the company. This research used a descriptive analysis method. The analyzing tools used in this research included the Business Model Canvas (BMC) and Strength, Weakness, Opportunities, Threats (SWOT) analysis. The portraits of the existing nine elements of BMC of PT Labas describe the business processes that have been run by the company at this time. The SWOT analysis from these nine elements resulted in several alternative business development strategies for PT Labas. The strategies that can be undertaken by PT Labas management include operational improvement, core-plasma partnership with the enlargement partners, innovation \& product quality improvement, market development, and business capital enhancement. BMC improvement is conducted by strengthening the elements of customer segment, channel, customer relationship, key resources, key activities, key partnership, and cost structure. The development of the BMC element provides changes to other elements.
\end{abstract}

Keywords: eel (Anguilla spp.), PT Labas, BMC, strategy, business development

\begin{abstract}
Abstrak: Tujuan dari penelitian ini adalah untuk menggambarkan model bisnis PT Labas dengan pendekatan Business Model Canvas (BMC), menyusun strategi pengembangan bisnis PT Labas, dan menggambarkan pengembangan BMC PT Labas. Penelitian ini menggunakan metode analisa deskriptif. Alat analisis yang digunakan dalam penelitian ini adalah Business Model Canvas (BMC) dan analisis Streanght Weakness Opportunities Threats (SWOT). Potret sembilan elemen BMC eksisting PT Labas, menggambarkan proses bisnis yang telah dijalankan oleh perusahaan saat ini. Hasil SWOT dari sembilan elemen tersebut menghasilkan beberapa alternatif strategi pengembangan bisnis bagi PT Labas. Strategi yang dapat dilakukan oleh manajemen PT Labas adalah strategi perbaikan operasional, strategi menjalin hubungan inti-plasma dengan mitra pembesaran, strategi melakukan inovasi \& peningkatan kualitas produk dan layanan, strategi pengembangan pasar, dan strategi penambahan modal usaha. Perbaikan BMC dilakukan dengan menguatkan pada elemen customer segment, channel, customer relationship, key resources, key activities, key partnership, dan cost structure. Pengembangan elemen BMC tersebut memberikan perubahan kepada elemen lain.
\end{abstract}

Kata kunci: ikan sidat (Anguilla spp.), PT Labas, BMC, strategi, pengembangan bisnis

\footnotetext{
${ }^{1}$ Corresponding author:

Email: hestiindripurwaty90@gmail.com
} 


\section{INTRODUCTION}

Indonesia has high sea fishery resources and is very rich in economic valued biota in both marine and freshwater areas. One of Indonesia's fishery resources is eel (Anguilla spp.). Eel is a type of consumed fish with a high economic value, both for local and overseas markets. This fish is very popular in overseas markets such as Japan, Hongkong, Holland, Germany and some other countries enabling it to have a potential as an export commodity (Napitupulu \& Budi, 2011). The total world's eel production up to 1990 was between 100,000-110,000 tons/year, and the number continued to increase. By 2011, the total production and consumption reached 255,284 tons/year (Heinsbroek, 1991; Monticini, 2014). Indonesia accounted for eight percent of the world's total fish production (Crook, 2014). Currently, the price of eel ranges from Rp160,000 to Rp245,000/kg consisting of 3-4 fish in average, and the selling price of eel fcan reach up to Rp1,5-2 million/kg if it is exported to Japan (KKP, 2016). In addition to the economic benefits of the eel, it also has good quality. Eel is a fish type that has a high nutritional content, rich in protein and vitamin $\mathrm{D}$ and $\mathrm{E}$ as well as in microprotein (Napitupulu \& Budi, 2011). Eel fish also contains a variety of unsaturated fatty acids, including EPA and DHA. EPA and DHA contents in fresh eel fish are $1.15 \%$ and $5.16 \%$, while those in kabayaki processed products are $0.70 \%$ and $1.29 \%$ (Widyasari, 2013).

The potential of eel fish in Indonesia is fairly high in reference to the abundance of eel fish sources. Indonesia has 6 species of eel fish out of 16 eel fish species in the world (Affandi, 2005). In Indonesia, eel fish is found in border areas of rivers with deep sea such as South Coast of Java Island, West Coast of Sumatra, East Coast of Borneo, Coast of Sulawesi, Maluku, Papua and West Irian (Napitupuli \& Budi, 2011). Unlike in other countries (e.g. Japan), Indonesian eel fish resources have not been widely utilized. Eel fish in Japan is used as basic ingredients of traditional food preparation (Unagi Kabayaki \& Shirayaki), in some countries in Southeast Asia, fishermen consume eel as a source of protein. Meanwhile, Indonesian eel fish is not widely known (Affandi, 2005; Siriraksophon et al. 2014). The eel fish industry in various countries began to develop at different times. Japan has started the commercial scale of eels since 1890, Taiwan has begun to develop its eel industry since 1989, and China conducted incentive eel farming in the mid 1970s (Shiraishi \& Crook, 2015).
Indonesia began to develop eel fish in 1995-1997, yet it still encounters difficulties to find seed (Herniati, 2005).

The utilization of eels for export is also very limited, as Indonesia currently only exports products of fresh fish or fish that have not been processed (Monticini, 2014). Indonesia exports it to countries in East Asia, such as China, Hong Kong, Japan, South Korea, and Taiwan. In addition to Indonesia, Southeast Asian countries that export eels include the Philippines, Malaysia, Vietnam and Thailand (Shiraishi \& Crook, 2015). Exporting countries of fresh eels for cultivation to China, Hongkong, Japan, South Korea and Taiwan can be seen in Figure 1.

PT Laju Banyu Semesta (Labas) is a company whose business focuses on integrated eel cultivation industry that has been integrated from upstream to downstream. The process starts from the cultivation (enlargement) to the processing process into various products. The eel cultivation process at PT Labas utilizes technology effectively. This can be seen from the use of recirculation system while maintaining the glass ell and elver fingerling as well as pond enlargement by using running water system. This company can also make eel feed so that the company does not depend on the feed price in the market. The company has also created a brand in its processed products i.e. "Labasaki" as the acronym of Laju Banyu Semesta Asli Karya Indonesia. The processed products produced by the company are unagi, crispy eel fish, pepes, and sausage of eel fish. In addition to the advantages of the company, the current eel production at PT Labas still fluctuates each month. The internal data of the company show that the total production is $\pm 240 \mathrm{~kg} /$ month.

PT Labas has a production target in 2022 of one ton/day, so it requires an optimal strategy to achieve this target. The company needs to propose a strategic planning to deal with environmental conditions and existing business competition. It can start by describing the current business model and developing it. One strategy analysis tool that can be used to describe the condition is by using Business Model Canvas (BMC) approach. This model is a visualization of the nine elements shaping up the main building blocks. Its use is intended to facilitate problem identifications encountered by the company; therefore it is able to guide/develop strategies as the solutions for the company. 


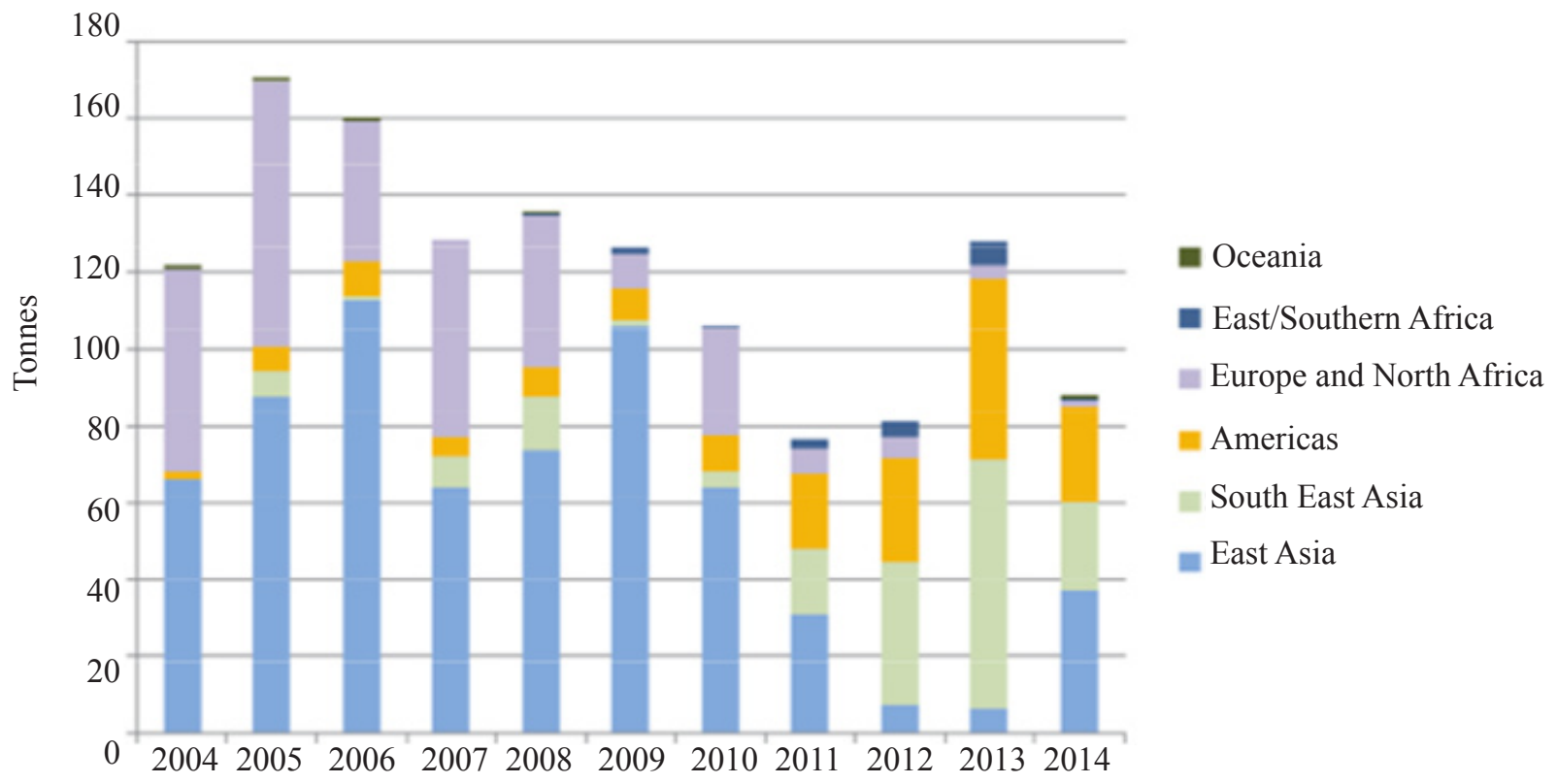

Figure 1. Exporting countries of eels to China, Honking, Japan, South Korea and Taiwan (Shiraishi \& Crok, 2015).

The research on eel fish has been performed numerously, starting from the cultivation to the development strategy aspects of eel fish industry. Nonetheless, the existing researches are dominated by those on the aspects of eel fish cultivation and genetics. Haryono (2008) conducted a study on the aspect of eel fish cultivation. Researches on the eel fish ecology, physiology, and genetic conservation had been conducted by Ndobe (2010) and Fahmi (2015). Yudiarto et al. (2012) and Subekti et al. (2011) conducted researches on the effect of giving feed formulation toward its impact of fish eel protein, fat and energy. After a number of researches on the aspects of cultivation and genetics, the current research on the eel fish strategy aspect begins to develop as performed by Bachtiar et al. (2013) and Widyasari (2013). They conducted researches on the marketing development strategy and industry of eel fish in the Fishery Management Unit (UPPB) of Lamongan and Pelabuhanratu. By referring to the previous research, this research was conducted to formulate a strategy \& describe the company's business model with Business Model Canvas (BMC) approach.

Various studies have also been conducted on the use of $\mathrm{BMC}$ in formulating corporate strategy. The research on BMC can be performed on big companies e.g. Silalahi (2014) and Anas et al. (2015) who conducted BMC analysis on the agribusiness division of Bank Rakyat Indonesia (BRI) and Bank Syariah X Cibinong Branch. The analytical tools used in the study were
BMC \& SWOT analyses with Focus Group Discussion (FGD), in-depth interviews, and questionnaires as data collection techniques. However, Anas et al. (2015) conducted a study by using the AHP analysis tool to determine which BMC elements are most influential/ require development compared to other BMC elements. This research formulated the business development strategy of PT Labas by using BMC and SWOT. The results of this study are expected to assist companies in solving the occurring problems.

The current problems faced by companies today are eel fish seeds still rely on catching in nature, difficult cultivation, fluctuated production scale, and processed products produced that have not been widely known by the public, and qualified human resources. Based on the explanation of the above problem formulation, the objectives of this research were to identify PT Labas business model based on BMC, to develop business strategy to achieve production target, and to develop PT Labas business model by using BMC approach.

The commodity that became the object of this research was the eel farming in PT Labas. The research scope covered the business model description and the business development strategy formulation of PT Labas. In addition, the scope of the study to be analyzed was to illustrate the business model of PT Labas by using BMC approach. The strategy implementation relies entirely on the management of PT Labas. 


\section{METHODS}

This research was conducted at PT Laju Banyu Semesta (Labas) at Cibening Village, Pamijahan Sub-district Bogor Regency. The data collection was conducted from August to November 2016. The selection of research location was done by purposive sampling. The method used in this research was descriptive analysis with BMC as the analytical tool approach.

There are two types of data in this research i.e. primary and secondary data. The data were obtained from internal and external companies. The primary data were collected by direct observation, Focus Group Discussion (FGD), in depth interview, and questionnaire, while the secondary data were in forms of PT Labas company data and related literature reviews. The technique of determining the respondents was by using purposive sampling. The number of respondents used were five internal respondents (corporate managerial) respondents and three external respondents (one academic and two enlargement partners). These respondents were selected based on their respective competencies. The research framework can be seen in Figure 2.

The steps of data processing and analysis conducted in this research are as follows:

The first stage of data analysis was to identify the existing business model of the company. This identification was conducted by in-depth interviews with internal respondents of the company. This identification was performed by using BMC approach. The company's business model was mapped to nine BMC elements i.e. customer segment (CS), value proposition (VP), channels $(\mathrm{CH})$, customer relationships $(\mathrm{CR})$, revenue stream (RS), key resources (KR), key activities (KA), key partnership (KP), and cost structure (C\$). The results of the nine elements are based on on-going and actual business conditions at PT Labas.

The second stage was the SWOT analysis and the determination of the company's strategic alternatives. SWOT analysis (Strength, Weaknesses, Opportunity, and Threat) was performed on all of BMC elements. According to Rangkuti (2000), SWOT analysis is utilized to identify various factors, both external and internal factors to formulate corporate strategy. Sources of information used in this analysis were obtained from PT Labas management based on the conditions that occurred. The analysis results of each element were classified based on its aspects i.e. strengths, weaknesses, opportunities, and threats. The Internal (outputs and weaknesses) and external (opportunities and threats) factors were determined by priorities with a priority scale. The scale used was 1 to 5 for strength and opportunity aspects, while the scale -1 to -5 was for trivial and threat aspects. Determination of SWOT priority by 5 is a strength and good opportunity for the company, while -5 is a weakness and threat that need to be anticipated by the company (Ibnussina, 2014). Furthermore, SWOT matrix is formulated to create alternative corporate strategy in developing eel fish business model.

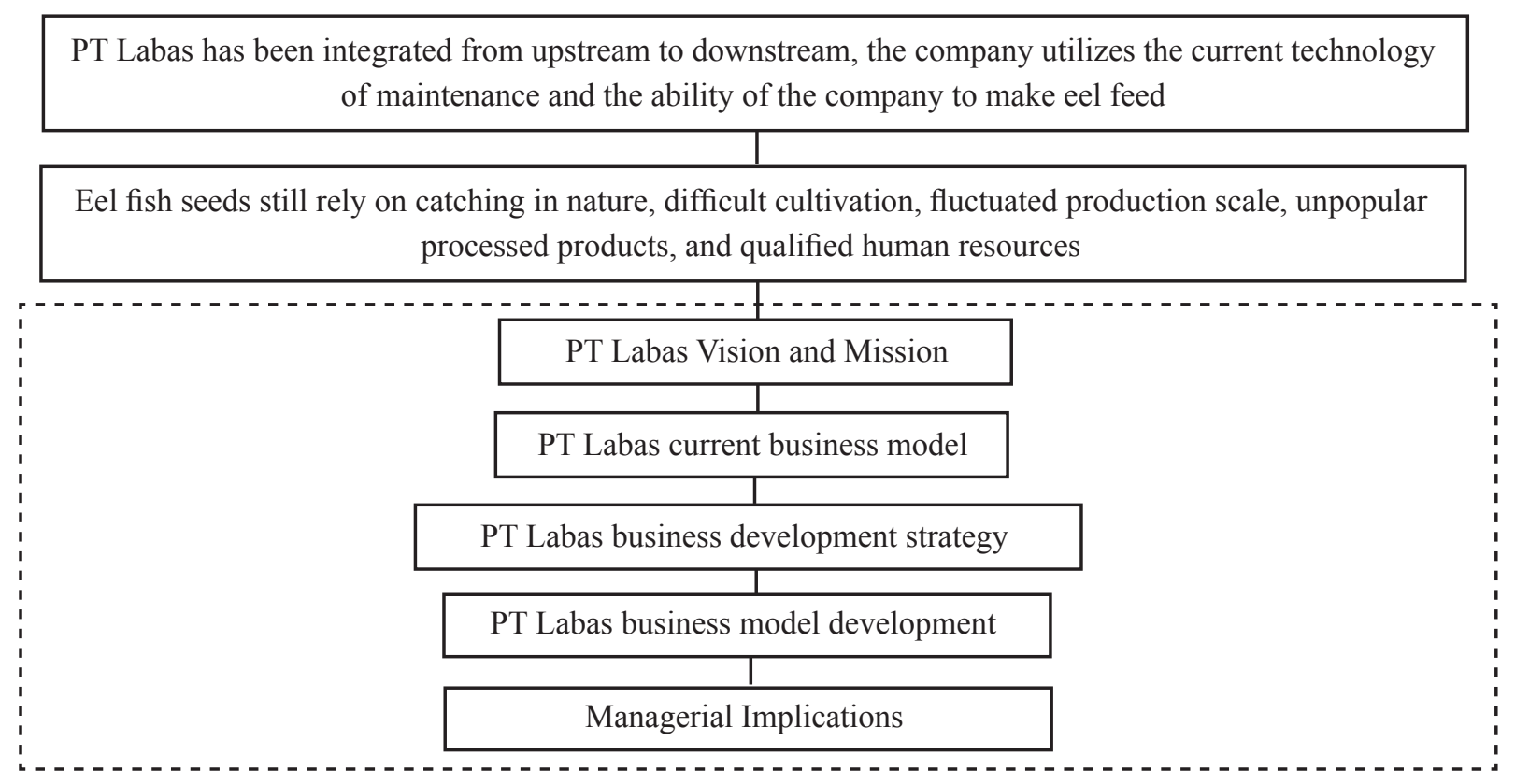

Figure 2. Research framework 
The third stage was the development of the company business model based on BMC. Having obtained some business development strategies of the company, the next step was to give recommendation to the company. Recommendations were given in the forms of several new business model alternatives in accordance with the predetermined strategies. The recommendation of developing a new business model of the company will be the goal to achieve the company's production target. The development of PT Labas business model is conducted by BMC approach. Changes or improvements to the business model are needed to achieve the research objectives i.e. the effort of PT Labas business model development.

\section{RESULT}

\section{The Existing PT Labas BMC Identification}

The identification of PT labas BMC can be seen in Figure 3. PT Labas currently serves education and non-education customer segments. The value offered is product innovation, halal certified products, superior seed providers, and self-feed production. Customer relationships are made with personal approach, exhibition, and core-plasma. Sales channels occur through direct and indirect sales. The main revenue comes from the sale of feed seeds, processed products, and service providers. In addition, the resources are in the forms of human resources, farming, processing unit, and feed mill. The key activities include seed maintenance, enlargement, processing and sales activities. The current partnership consists of seed farmers, enlargement partners, government, universities, and raw material suppliers. The cost structure consists of production and operational costs. Widyasari (2013) explains that the high demand for eel fish for consumption resulted in the transfer of eels from nature to cultivation. This is also performed to maintain the sustainability of eel business. The company has a restocking program (the release of eels to nature), so that the sustainability of the eel \& company business resources can be maintained.

\section{The Strategies of PT Labas Business Model Development}

According to Osterwalder and Pigneur (2015), the BMC approach can highlight that a weakness in a single block of elements can affect one or more elements of other blocks, or the entire business model. One way to evaluate the business model is to conduct a SWOT analysis. After identifying the current nine elements of BMC, the next step is to perform a SWOT analysis on them. The nine elements of BMC are classified into four strategic issues i.e. value proposition, revenue stream and cost structure, operations (key resources, key activities, and key partnerships), and customer relationships (customer segments, channels, and customer relationship). In addition to formulating the company strategic planning, the SWOT analysis results are used as the basis of planning the improvement of PT Labas business model.

\begin{tabular}{|c|c|c|c|c|}
\hline \multirow[t]{2}{*}{$\begin{array}{l}\text { Key partners } \\
\text { - Seed Farmers } \\
\text { - Processing } \\
\text { Partnership } \\
\text { - } \text { Government } \\
\text { - University } \\
\text { - Raw material } \\
\text { supplier }\end{array}$} & $\begin{array}{l}\text { Key activities } \\
\text { - } \text { Cultivation } \\
\text { - Processing Stages } \\
\text { - Promotion } \\
\text { - Feed production } \\
\text { - Training and } \\
\text { consultation }\end{array}$ & \multirow[t]{2}{*}{$\begin{array}{l}\text { Value Propositions } \\
\text { - Product Innovation } \\
\text { - Halal certified } \\
\text { products } \\
\text { - Superior seed supplier } \\
\text { - Independent feed } \\
\text { production }\end{array}$} & $\begin{aligned} & \text { Customer } \\
& \text { relationships } \\
\cdot & \text { Personal } \\
\cdot & \text { Exhibition/ } \\
\cdot & \text { events }\end{aligned}$ & \multirow{2}{*}{$\begin{array}{l}\text { Customer segments } \\
\text { - Education customers } \\
\text { 1. Enlargement Individuals } \\
\text { 2. Cultivation training } \\
\text { participant } \\
\text { 3. Farm visit customer } \\
\text { 4. Exhibition customer } \\
\text { - Non-education customers } \\
\text { 1. Japanese restaurants } \\
\text { 2. Hotels }\end{array}$} \\
\hline & $\begin{array}{l}\text { Key resources } \\
\text { - H \& R D } \\
\text { - Cultivation Farm } \\
\text { - Processing Unit } \\
\text { - Feed factory }\end{array}$ & & $\begin{array}{l}\quad \text { Channels } \\
\text { - Direct } \\
\text { - Indirect }\end{array}$ & \\
\hline \multicolumn{3}{|c|}{$\begin{array}{l}\text { Cost Structure } \\
\text { - Production Cost } \\
\text { - Operational Cost }\end{array}$} & \multicolumn{2}{|c|}{$\begin{array}{l}\text { Revenue Streams } \\
\text { - Seed Selling } \\
\text { - Feed Selling } \\
\text { - Processed Product Selling } \\
\end{array}$} \\
\hline
\end{tabular}

Figure 3. The existing PT Labas BMC 


\section{SWOT Priority Determination of PT Labas BMC}

The SWOT priority results are performed on a scale of one to five on strength and opportunity aspects, and minus one to five on the weakness and threat aspects. Determining SWOT priorities by five is a good advantage and an opportunity for the company, while minus five shows the weakness and threat that must be anticipated by the company. According to Coes (2014), BMC users are at least aware of the company limitations and know how to overcome them; therefore, the business model developers can also consider and adjust to the conditions of the company or use a customized business model tool.

Hvilsom (2012) explains that the business model development needs to rethink the overview of the internal and external environments of the company. The SWOT analysis in this study identified the internal environment (strengths and weaknesses) and the external environment (opportunities and threats). The SWOT priority results for each element of PT Labas BMC can be seen in Table 1 .

Table 1. SWOT priority of all elements of PT Labas BMC

\begin{tabular}{|c|c|c|c|c|}
\hline \multirow{2}{*}{$\begin{array}{l}\text { Element of } \\
\text { BMC }\end{array}$} & \multicolumn{2}{|c|}{ Internal Factor (IF) } & \multicolumn{2}{|c|}{ External Factor (EF) } \\
\hline & Strength & Weakness & Opportunity & Threat \\
\hline $\begin{array}{l}\text { Customer } \\
\text { Segment }\end{array}$ & $\begin{array}{l}\text { The well segmented- } \\
\text { based customers }\end{array}$ & $\begin{array}{l}\text { Only a few of Japanese } \\
\text { hotels \& restaurants } \\
\text { have been served }\end{array}$ & $\begin{array}{l}\text { The Indonesian society is } \\
\text { not familiar with eel fish }\end{array}$ & Company competitors \\
\hline $\begin{array}{l}\text { Value } \\
\text { Proposition }\end{array}$ & $\begin{array}{l}\text { Processing has been } \\
\text { certified (halal \& } \\
\text { acceptable processing) }\end{array}$ & $\begin{array}{l}\text { Limited Production } \\
\text { Capacity }\end{array}$ & $\begin{array}{l}\text { Creation of varied } \\
\text { processed products }\end{array}$ & Company competitors \\
\hline Channel & $\begin{array}{l}\text { Customers can choose } \\
\text { the communication } \\
\text { channel in accordance } \\
\text { with their desire } \\
\text { (online/direct media) }\end{array}$ & $\begin{array}{l}\text { The company needs } \\
\text { a fee to conduct } \\
\text { promotions through } \\
\text { direct channels } \\
\text { (exhibitions) }\end{array}$ & $\begin{array}{l}\text { The number of hotels \& } \\
\text { restaurants that cooperate } \\
\text { with the company is still } \\
\text { small }\end{array}$ & $\begin{array}{l}\text { Competitors of the } \\
\text { company have a higher } \\
\text { continuity \& quantity } \\
\text { of production }\end{array}$ \\
\hline $\begin{array}{l}\text { Customer } \\
\text { Relationship }\end{array}$ & $\begin{array}{l}\text { The company provides } \\
\text { excellent service to } \\
\text { customers and partners }\end{array}$ & $\begin{array}{l}\text { Individuals for } \\
\text { enlargement are still at } \\
\text { the stage of learning in } \\
\text { the eel fish cultivation }\end{array}$ & $\begin{array}{l}\text { Individuals or groups start } \\
\text { to get interested in eel } \\
\text { farming }\end{array}$ & $\begin{array}{l}\text { Competitors of the } \\
\text { company have a higher } \\
\text { continuity \& quantity } \\
\text { of production }\end{array}$ \\
\hline $\begin{array}{l}\text { Revenue } \\
\text { Stream }\end{array}$ & $\begin{array}{l}\text { The profit margin of the } \\
\text { company is good }\end{array}$ & - & $\begin{array}{l}\text { New sources of revenue } \\
\text { from sales of new } \\
\text { processed products }\end{array}$ & $\begin{array}{l}\text { Margin is threatened by } \\
\text { the price of seed in the } \\
\text { field }\end{array}$ \\
\hline Key Resources & $\begin{array}{l}\text { Eel cultivation is } \\
\text { conducted by using } \\
\text { technology }\end{array}$ & $\begin{array}{l}\text { Limited production } \\
\text { facilities and } \\
\text { infrastructure }\end{array}$ & $\begin{array}{l}\text { The addition of marketing } \\
\text { workforce can improve } \\
\text { company performance }\end{array}$ & $\begin{array}{l}\text { Eel fish seeds still rely } \\
\text { on the capture from the } \\
\text { nature }\end{array}$ \\
\hline Key Activities & $\begin{array}{l}\text { The running business } \\
\text { has been integrated } \\
\text { from upstream to } \\
\text { downstream }\end{array}$ & $\begin{array}{l}\text { Company production } \\
\text { capacity is still low }\end{array}$ & $\begin{array}{l}\text { Indonesian society is still } \\
\text { unfamiliar with eel fish }\end{array}$ & $\begin{array}{l}\text { Eel fish company has } \\
\text { a larger production } \\
\text { capacity }\end{array}$ \\
\hline $\begin{array}{l}\text { Key } \\
\text { Partnership }\end{array}$ & $\begin{array}{l}\text { Have a good } \\
\text { relationship with the } \\
\text { partners }\end{array}$ & $\begin{array}{l}\text { The government has } \\
\text { not yet focused on the } \\
\text { development of eel } \\
\text { cultivation business }\end{array}$ & $\begin{array}{l}\text { Cooperating with the } \\
\text { partners of enlargement }\end{array}$ & $\begin{array}{l}\text { Seed partners are } \\
\text { offered higher seed } \\
\text { prices by the company } \\
\text { competitors }\end{array}$ \\
\hline Cost Structure & $\begin{array}{l}\text { The cost structure } \\
\text { corresponds to the } \\
\text { business model }\end{array}$ & $\begin{array}{l}\text { The company is still } \\
\text { spending a lot of } \\
\text { promotional costs } \\
\text { through the exhibition }\end{array}$ & $\begin{array}{l}\text { Cost efficiency from } \\
\text { substitution of the } \\
\text { supporting materials }\end{array}$ & $\begin{array}{l}\text { The raw material price } \\
\text { fluctuations }\end{array}$ \\
\hline
\end{tabular}




\section{Strategic Alternative for the Business Development of PT Labas}

PT Labas BMC development and improvement have been adjusted with SWOT Development and improvement of the BMC of PT Labas had been adjusted with the analysis results on the nine elements of BMC. Furthermore, alternative strategies are determined to support the development of PT Labas business model. Strategies can be performed in business development of PT Labas based on the business model i.e. the scope of business strategy. This strategy is implemented by developing the company operational system, improving the quality of products and services, and developing the market. Figure 4 illustrates the alternative strategies of PT Labas. In order to develop the business model of PT Labas, there are five strategies from the SWOT analysis that will be the focus of the company. The strategies are as follows: strategy on the operational system improvement and repair, strategy on core-plasma relationship with the partners of enlargement, strategy on innovation \& improvement of the qualities of products and services, strategy on market development, and strategy on venture capital enhancement.
In the phase of repair and improvement of the operational systems, the company plans and sets the budget costs and determines what is required to be prepared. In this preparatory stage, the company also needs to socialize the company plan to all its employees so that the company's goals can be understood and can be a common focus.

The next stage is that the company can build a good synergy with its enlargement partners. The relationship or synergy between the company and its cultivation partners can be built by establishing a core plasma relationship. The core pattern of plasma is the pattern of partnership relationship between partner groups and core companies (Kamil, 2006). According to Sukardi et al. (2006), a cell will develop well if the nucleus and plasma work together according to their functions. PT Labas as the core has the function to serve its partners and provide the facilities \& infrastructure needed by them. Based on the results of the interviews with its cultivation partners, PT Labas as the core company has carried out its responsibilities well. The functions of the company are to serve its cultivation partners with quick responses when they require inputs from the company and to provide good quality of eel fish seeds and feed according to the needs of the fish.

\begin{tabular}{|c|c|c|}
\hline EF $\longrightarrow$ IF & Strength (S) & Weakness (W) \\
\hline \multirow{2}{*}{ Opportunities $(\mathrm{O})$} & Strategy S-O & Strategy W-O \\
\hline & $\begin{array}{l}\text { Creating processed products in accordance with } \\
\text { the Indonesian taste (S2, S7, O1, O2, O5) } \\
\text { Recruiting the marketing employees (S7, S8, } \\
\text { O6, O3, O4) } \\
\text { Target customers of communities and } \\
\text { housewives (S1, S7, O1, O2, O5) } \\
\text { Target customers of communities and } \\
\text { housewives (S1, S7, O1, O2, O5) }\end{array}$ & $\begin{array}{l}\text { Building training \& information center (W3, O1, } \\
\text { O4) } \\
\text { Initiating \& creating synergy with the } \\
\text { government (especially CTF) (W5, O1) } \\
\text { Building a nuclear-plasma relationship with the } \\
\text { enlargement partners (W1, W2, O7, O4) } \\
\text { Focusing on reaching non-education customer } \\
\text { segments (W2, W4, O3, O6) }\end{array}$ \\
\hline \multirow[t]{2}{*}{ Threat $(\mathrm{T})$} & Strategy S-T & Strategy W-T \\
\hline & $\begin{array}{l}\text { Searching for alternatives to eel fish seed areas } \\
(\mathrm{S} 7, \mathrm{~S} 8, \mathrm{~T} 2, \mathrm{~T} 3, \mathrm{~T} 4, \mathrm{~T} 5) \\
\text { Establishing research collaboration with related } \\
\text { institutions (LIPI, University, etc.) (S2, S6, S7, } \\
\mathrm{S} 8, \mathrm{~T} 1, \mathrm{~T} 3)\end{array}$ & $\begin{array}{l}\text { Reaching market segments that do not yet know } \\
\text { the eels (W2, W4, T1) } \\
\text { Maintaining continuity of training } \\
\text { implementation (W1, W2, W5, T1) } \\
\text { Establishing a sales chain in the form of an agent } \\
\text { (W2, W4, W6, T1) } \\
\text { Enhancing the venture capital (W1, W5, W6, O1, } \\
\text { O4, O5) }\end{array}$ \\
\hline
\end{tabular}

Figure 4. SWOT Matrix of all BMC elements 
The company can start by making a cooperation agreement with it partners so that they should resell their yields back to the company. Synergy between the core company and cultivation partners can provide a variety of benefits for both that is increasing the company production, expanding the marketing network, opening new markets, finding alternatives for the eel fish seed centers, and supporting the sustainability of the business. Therefore, it is important for the company to know the model of partnership in accordance with its business model that has been implemented.

The next stage is to innovate and increase the quality of products and services. Improvement in the quality of services must be conducted by the company, so that its customers become loyal. Loyal customers can be interpreted as customers who make repeat purchases and refer the company products to others. Service communication to customers has a significant influence on customer loyalty (Logahan \& Princess, 2013; Jauhari, 2015). The company can start by performing customer data collection so that programs can be communicated personally to the customers.

The next stage is to carry out market development which can be performed by establishing the company agencies and by establishing cooperation with the supermarkets to reach the non-education customer segment. The Ministerial Decree of Agriculture No. 940/Kpts/OT.210/10/1997 states that an agency pattern is a partnership relationship in which there is a group of partners who carry out the marketing of products and services of the partner company business. The agency pattern can be adjusted to the current condition of the company in which the amount of production is still fluctuated. Therefore, the agency pattern can be started by helping the company to disseminate information and educate people on eel fish in Indonesia. The company also needs to reach the non-educated customer segment, considering the fact that there are many Japanese hotels and restaurants and individuals that have not been approached by the company. Cooperation development takes place so that company can reach greater number of non-educational customers and expand its marketing network, thus resulting in the increase of the company income. The next stage is to increase working capital which requires attention from the company. According to Sukoco et al. (2015) and Irawan (2016), working capital affects the profitability of the company.

\section{Development of the Business Model Canvas (BMC) of PT Labas}

The development of the BMC of PT Labas is conducted by designing the business model of the company. The business model was designed using ideation/idea generation method that is by issuing ideas to get the best idea. According to Luoma (2014), if it is in accordance with the identified strategy issues, the company can develop a new business model framework to answer the business needs of the company in the future. These strategic issues can be a consideration for the company to determine which elements will be developed in creating a new business model. Osterwalder \& Pigneur (2015) also explained that business model changes start from the areas identified by the SWOT analysis.

Osterwalder and Pigneur (2015) explain that the development of a business model can come from several BMC element centers and is very influential on some other BMC elements. The development of the BMC of PT Labas selected seven elements that become the priority of improvement that is customer segment, channel, customer relationship, key resources, key activities, key partnership, and cost structure. The addition of a new aspect is indicated by the sign of "*". Figure 5 shows a picture of the improvement of BMC of PT Labas.

\section{Managerial Implication}

After performing the repair of BMC of PT Labas analyzed using SWOT analysis, an alternative strategy used by company to support the repair program of the BMC was determined. The strategies for the development of the business model of the company include the aspects of operations, products and services, marketing and market development, and business expansion. The strategies for the improvement and development of PT Labas business model consist of several steps, namely: the preparation phase of the repair. In this stage, the company plans and sets the budgeted costs and determines what is required to be prepared. The company also needs to socialize its plan to the management.

Determination of the first strategy that needs to be conducted by PT Labas management is the improvement on the whole employees engaged in operations (starting from cultivation, maintenance, to processing of the eel fish). The operational employees require specific skills 
that will make them to be experts in their field. The employee skills are very important in supporting the business of PT Labas. The availability and consistency of raw materials and products need to be improved by PT Labas. The company can conduct a careful analysis on the customer demand and better supply management. The company requires to prepare resources for business activities and establish the $\mathrm{R} \& \mathrm{D}$ section that will have responsibility for quality control of raw materials and company needs.

Implementation of the second strategy is by establishing a nuclear-plasma relationship with its enlargement partners. After the improvement of the company operational system, the next step is to strengthen the core-plasma relationship with its partners. Since the production capacity of PT Labas is still low (it has not yet reached the production target), it should establish such cooperation so that the company can increase the amount of production. The company acts as the nucleus and the enlargement partners function as plasmas in which they must their resell their harvest of the eel fish to the core company; therefore, it can be more effective in achieving its target.

The implementation of the third strategy is to innovate and improve the quality of products and services. After the company can increase its production capacity, it can make improvements on the produced processed products. Product innovation can be carried out by making the processed products in accordance with the tastes of the Indonesian society so that the people who are not familiar with the eel fish can be interested in trying the processed products. In addition to the innovation, the company also can simultaneously improve the quality of its processed products especially the unagi product as it is a processed product that has been widely known by the world community, especially by Japan. Therefore, the number of the company customers can grow continuously.

\begin{tabular}{|c|c|c|c|c|}
\hline \multirow{2}{*}{$\begin{array}{l}\text { Key partners } \\
\text { - Seed Farmers } \\
\text { - Processing } \\
\text { Partnership } \\
\text { - Government } \\
\text { - University } \\
\text { - Raw material } \\
\text { supplier } \\
\text { - Enlargement } \\
\text { partners* } \\
\text { - Fishery } \\
\text { Organizations* }\end{array}$} & $\begin{array}{l}\text { Key activities } \\
\text { - Cultivation } \\
\text { - Processing Stages } \\
\text { - Promotion } \\
\text { - Feed production } \\
\text { - Training and } \\
\text { consultation } \\
\text { - Partner synergy* }\end{array}$ & $\begin{array}{l}\text { Value Propositions } \\
\text { - Product Innovation } \\
\text { - Halal certified } \\
\text { products } \\
\text { - Superior seed supplier } \\
\text { - Independent feed } \\
\text { production }\end{array}$ & \begin{tabular}{|l}
\multicolumn{1}{|c}{ Customer } \\
relationships \\
- Personal \\
- Exhibition/ \\
- events \\
- Nucleus-plasma* \\
- minimarket (Self- \\
service)*
\end{tabular} & \multirow{2}{*}{$\begin{array}{l}\text { Customer segments } \\
\text { - Education customers } \\
\text { 1. Enlargement Individuals } \\
\text { 2. Cultivation training } \\
\text { participant } \\
\text { 3. Farm visit customer } \\
\text { 4. Exhibition customer } \\
\text { 5. Enlargement partners* } \\
\text { 6. Housewives* } \\
\text { - Non-education customers } \\
\text { 1. Japanese restaurants } \\
\text { 2. Hotels } \\
\text { 3. Individuals familiar with } \\
\text { eel fish* }\end{array}$} \\
\hline & $\begin{array}{l}\text { Key resources } \\
\text { - H \& R D } \\
\text { - Cultivation Farm } \\
\text { - Processing Unit } \\
\text { - Feed factory } \\
\text { - Supporting } \\
\text { facilities and } \\
\text { Infrastructure* }\end{array}$ & & $\begin{array}{l}\text { Channels } \\
\text { - Direct } \\
\text { - Indirect }\end{array}$ & \\
\hline \multicolumn{3}{|c|}{$\begin{array}{l}\text { Cost Structure } \\
\text { - Production Cost } \\
\text { - Operational Cost } \\
\text { - HRD recruitment cost* } \\
\text { - Cost for purchasing the harvests from the partners* } \\
\text { - Procurement cost of the supporting facility and infrastructure * }\end{array}$} & \multicolumn{2}{|c|}{$\begin{array}{l}\text { Revenue Streams } \\
\text { - Seed Selling } \\
\text { - Feed Selling } \\
\text { - Processed Product Selling } \\
\text { - Service provider* }\end{array}$} \\
\hline
\end{tabular}

Figure 5. Improvement of BMC of PT Labas (The addition of a new aspect is indicated by the sign of "*") 
The implementation of the fourth strategy is to conduct market development. It can be carried out by the company by firstly reaching the segment of noneducation customers, i.e. individuals who already know about eel fish products (unagi). The company can work together with supermarkets to sell its products so that people can directly buy the processed products in the supermarkets.

Implementation of the fifth strategy is capital enhancement. After the improvement of the operational system has been conducted by the company, it can increase production capacity, improve quality of processed products, and conduct market development. The company can search for investors who wish to cooperate in the enhancement of its capital.

\section{CONCLUSIONS AND RECOMMENDATIONS}

\section{Conclusions}

Description of the eel fish business model of PT Labas with the business model canvas approach (BMC) produces a business model mapped into the nine elements of BMC: customer segment (CS), value propositions (VP), channels $(\mathrm{CH})$, customer relationship (CR), revenue stream (CR), key activities (KA), key resources (KR), key partnership (KP), and cost structure (C \$). It also produces a new business model and an alternative strategy applied in the implementation of its business model

The strategies of PT Labas in developing its business include operational improvement, core-plasma partnerships with the partners of enlargement, innovation \& product quality improvement, market development and business capital enhancement.

BMC improvement is conducted by strengthening the elements of customer segment, channel, customer relationship, key resources, key activities, key partnership, and cost structure. The development of the BMC element provides changes to other elements.

\section{Recommendations}

The development of BMC can implement the stages that have been agreed previously. The management of PT Labas can conduct other research development by taking into consideration the proposed BMC improvements. The company can start by conducting research on how to make effective plasma core patterns to increase production quantities. Further studies on how to decide a model/pattern for the plasma core relationship suitable to be applied to the conditions of the company and its partners for enlargement.

\section{REFERENCES}

Affandi R. 2005. Startegi pemanfaatan sumberdaya ikan sidat (Anguilla spp.) di Indonesia.Jurnal Biologi Indonesia 5(2): 77-81.

Anas N, Beik IS, Tanjung H. 2015. Model bisnis kanvas layanan haji PT Bang syariah X Cabang Cibinong. Jurnal Aplikasi Model Bisnis dan Manajemen 1(2):75-86. Doi 10.17358/JABM.1.2.75

Bachtiar N, Nuddin H, Harsuko R. 2013. Strategi pengembangan pemasaran ikan sidat (Anguilla bicolor) di Unit Pengelolaan Perikanan Budidaya (UPPB) Desa Deket Kecamatan Deket Kabupaten Lamongan Jawa Timur. API Student Journal 1(1):29-36.

Coes B. 2014. Critically assessing the strengths and limitations of the business model canvas [thesis] Enschede: University of Twente.

Crook V. 2014. Slipping Away: International Anguilla Eel Trade and The Role of The Philippines. United Kingdom: TRAFFIC International \& ZSL.

Fahmi MR. 2015. Short communication: conservation genetic of tropical eel in Indonesia waters based in polulation genetic study. Pros Sem Nas Masy Biodiv Indon. 1(1): 38-43. Doi 10.13057// psnmbi/m010106.

Haryono. 2008. Sidat, belut bertelinga: potensi dan aspek budidaya. Fauna Indonesia 8(1): 22-26.

Heinsbroek LTN. 1991. A review of eel culture in Japan and Europe. Aquaculture and Fisheries Management 22(1): 57-72.

Herianti I. 2005. Rekayasa lingkungan untuk memicu perkembangan ovarium ikan sida (Anguilla bicolor). Oseanologi dan Lommologi Indonesia 37: 25-41. https://doi.org/10.1111/j.13652109.1991.tb00495.x.

Hvilsom L. 2012. Business model components \& their interrelations [thesis]. Copenhagen: Copenhagen Business School.

Ibnussina. 2015. Strategi pengembangan signature coffee shop dengan pendekatan model bisnis kanvas [tesis]. Bogor : Institut Pertanian Bogor. 
Irawan MRN. 2016. Pengaruh modal usaha dan penjualan terhadap laba usaha pada perusahaan penggilingan padi UD. Sari Tani Tenggerejo Kedungpring Lamongan. Jurnal Penelitian Ekonomi dan Akuntansi 1(2): 75-82.

Jauhari A. 2015. Analisa pengaruh relationship marketing terhadap loyalitas pelangan pelanggan perusahaan batik "Joglo Suminar" Kediri. Jurnal Cendekia 13(2): 74-82.

Kamil M. 2006. Strategi kemitraan dalam membangun PNF melalui pemberdayaan masyarakat (model, keunggulan, dan kelemahan. http://file.upi.edu/ Direktori/SPS/PRODI.PENDIDIKAN_LUAR SEKOLAH/196111091987031-MUSTOFA_ KAMIL/Bhaan_kuliah/KEMITR 1.PDF [27 Januari 2017].

[KKP] Kementerian Kelautan dan Perikanan. 2016. Teknologi Nanobubble Tingkatkan Pertumbuhan Ikan Sidat. http://kkpnews.kkp.go.id/index.php/ teknologi-nanobubble-tingkatkan-pertumbuhanikan-sidat/ [4 Mei 2016].

Logahan JM, Putri YTE. 2013. Pengaruh komunikasi pelayanan dan kepuasan terhadap loyalitas pelanggan di 7-eleven Buaran. Binus Business Review 4(2): 886-896. https://doi.org/10.21512/ bbr.v4i2.1404.

Luoma O. 2014. A contextual business model framework: business model development in a product-service systems context [thesis]. Tampere: University of Tampere

Monticini P. 2014. Eel (Anguilla spp.): Production and Trade According to Washington Convention Legislation. Roma: Globefish FAO.

Napitupulu RJ, Budi H. 2011. Pengolahan Ikan Sidat. Jakarta: Sekolah Tinggi Perikanan.

Ndobe S. 2010. Struktur ukuran glass ell ikan sidat (Anguilla marmorata) di muara sungai Palu, Kota Palu, Sulawesi Tengah. Media Litbang Sulteng 3(2):144-150.

Osterwalder A, Pigneur Y. 2015. Business Model Generation Cetekan ke-8. Jakarta: PT Elex
Media Komputindo.

Rangkuti F. 2000. Analisis SWOT Teknik Membedah Kasus Bisnis. Jakarta: PT. Gramedia Pustaka Utama.

Shiraishi H, Crook V. 2015. Eel Market Dynamics: An Analysis Of Anguilla Production, Trade And Consumption In East Asia. Tokyo: Traffic.

Silalahi KA. 2014. Analisis model bisnis pada divisi agribisnis Bank Rakyat Indonesia menggunakan pendekatan model bisnis kanvas [tesis]. Bogor: Institut Pertanian Bogor.

Siriraksophon S, Ayson FG, Sulit VT. 2014. Potential and prospects of Southeast Asian eel resources for sustainable fisheries and aquaculture development. Southeast Asian Fisheries Development Center (SEAFDEC) 12(2):7-13.

Subekti S, Prawesti M, Arief M. 2011. Pengaruh kombinasi pakan buatan dan pakan alami cacing sutera (Tubifex tubifex) dengan prsentase yang berbeda terhadap retensi protein, lemak, dan energy pada ikan sidat (Anguilla bicolor). Jurnal Kelautan 4(1): 90-95.

Sukardi P, Margiwiyatno A, Rosyad A, Tobari, Santoro J, Anwar N. 2006. Model hubungan inti-plasma pada industri akuakultur tambak udang.Jurnal Pembangunan Pedesaan 6(1): 57-69.

Sukoco ARF, Endang MGWI, Zahroh ZA. 2015. Pengelolaan modal kerja usaha mikro untuk memperoleh profitabilitas. Jurnal Administrasi Bisnis 22(1): 1-9.

Widyasari RAHE. 2013. Disain terpadu pengembangan industri perikanan sidat Indonesia (Anguilla spp) berkelanjutan di Palanuhanratu Kebupaten Sukabumi Provinsi Jawa Barat [disertasi].Bogor: Institut Pertanian Bogor.

Yudiarto S, Arief M, Agustono. 2012. Pengaruh penambahan atraktan yang berbeda dalam pakan pasta terhadap retensi protein, lemak, dan energy benih ikan sidat (Anguilla bicolor) stadia elver. Jurnal Ilmiah Perikanan dan Kelautan 4(2): 135-140. 